\title{
Developing a framework to assess the cost- effectiveness of COMPARE - a global platform for the exchange of sequence-based pathogen data
}

\author{
F. Alleweldt ${ }^{(1)^{*}}$, Ş. Kara ${ }^{(1)}$, A. Osinski ${ }^{(1)}$, P. van Baal ${ }^{(2)}$, K. Kellerborg ${ }^{(2)}$, \\ F.M. Aarestrup ${ }^{(3)} \&$ M. Koopmans ${ }^{(4)}$ \\ (1) Civic Consulting, Potsdamer Strasse 150, D-10783 Berlin, Germany \\ (2) Institute of Health Policy and Management, Erasmus University, Rotterdam, Bayle Building, Campus Woudestein, \\ Burgemeester Oudlaan 50, 3062 PA Rotterdam, the Netherlands \\ (3) National Food Institute, Technical University of Denmark, Søltofts Plads, Building 221, Room 210, 2800 Kgs., \\ Lyngby, Denmark \\ (4) Department of Viroscience, Erasmus MC, P.O. Box 2040, Ee1726, 3000 CA Rotterdam, the Netherlands \\ *Corresponding author: alleweldt@civic-consulting.de
}

\section{Summary}

Analysing the genomic data of pathogens with the help of next-generation sequencing (NGS) is an increasingly important part of disease outbreak investigations and helps guide responses. While this technology has already been successfully employed to elucidate and control disease outbreaks, wider implementation of NGS also depends on its cost-effectiveness. COMPARE - short for 'Collaborative Management Platform for detection and Analyses of (Re-) emerging and foodborne outbreaks' - is a major project, funded by the European Union, to develop a global platform for sharing and analysing NGS data and thereby improve the rapid identification, containment and mitigation of emerging infectious diseases and foodborne outbreaks. This article introduces the project and presents the results of a review of the literature, composed of previous relevant cost-benefit and cost-effectiveness analyses. The authors also outline the implications for a methodological framework to assess the costeffectiveness of COMPARE and similar systems.

\section{Keywords}

COMPARE - Cost-benefit - Cost-effectiveness - Detection - Genomic information Next-generation sequencing - Pathogen - Surveillance.

\section{Introduction}

Analysing the genomic data of pathogens is an increasingly important part of disease outbreak investigations and helps guide responses $(1,2)$. The most advanced group of methods for performing whole-genome sequencing of pathogens, next-generation sequencing (NGS), enables researchers to generate "complete genomic information from the isolate or sample, independent of both the sector (public health, veterinary health, food safety), and the type of pathogen (viruses, bacteria, parasites)' (3). The outputs of NGS (sequence data) 'provide one common language that can be exchanged and compared between laboratories and over time' (3), and can be combined with contextual information, such as clinical, microbiological, or epidemiological data. The impact of NGS on microbiology is considered to have been 'revolutionary' (1), with applications of NGS ranging from infectious disease diagnostics and hospital infection-control surveillance programmes, to investigating community outbreaks and predicting antibiotic resistance through the identification of known resistance genes. A number of recent studies have highlighted the importance of NGS for surveillance, tracking diseases, and identifying outbreaks $(1,4,5,6,7,8,9)$. NGS is also widely used in research studies and increasingly applied as a supplement for clinical diagnostics and surveillance.

However, the costs of implementing NGS in routine diagnostics and surveillance remain high in comparison to the mainly phenotypic testing currently in use. The costs involved in implementing NGS include direct and recurrent costs associated with producing the data, as well as investment costs associated with building and running the infrastructure for sharing and analysing the large amount of data produced through NGS.

COMPARE - short for Collaborative Management Platform for detection and Analyses of (Re-) emerging and 
foodborne outbreaks - is a major project to develop a global platform for sharing and analysing NGS data. Started at the beginning of 2015, COMPARE is funded by Horizon 2020, the European Union's (EU) research and innovation programme. It is a collaboration between 28 European partners - including leading institutions in the field of emerging epidemics and foodborne outbreaks - and will run across a total span of five years. COMPARE aims to facilitate the early identification and control of relevant outbreaks and the correct identification of the potential source(s), resulting in considerable savings for the European primary and secondary food industry, as well as reduced illness for consumers. In addition, early detection and control of potentially notifiable disease outbreaks in European farm animals are expected to reduce control costs, as well as the consequences of trade restrictions (3).

After introducing the project, this article presents the results of a literature review of previous relevant cost-benefit and cost-effectiveness analyses, and outlines the implications for a methodological framework to assess the cost-effectiveness of COMPARE and similar systems. This framework will be developed and applied during the project's implementation.

\section{The surge in genomic data and the COMPARE system}

Whole-genome sequencing allows the entire DNA profile of pathogens to be mapped out at one time. For this purpose, NGS - like older sequencing technologies - begins with the collection and extraction of DNA from a sample. Then, 'random DNA fragments are created that contain adapter sequences that are complementary to platform-specific PCR and sequencing primers. DNA is fragmented, and additional processing (e.g. end-repair, A-tailing, 'barcoding') is completed. [For viruses], PCR amplification of the library is needed before sequencing' (10). The library is then sequenced using one of several NGS platforms available.

Replacing first-generation platforms, which used Sangerbased chemistries and capillary-based instruments, NGS technologies involve the parallel sequencing of millions of DNA fragments at the same time. The technological advances of NGS have led to a sharp drop in the costs of DNA sequencing, accompanied by a massive surge in output data, which is expected to continue rising to unprecedented levels in the coming years (3). Given the large amount of data produced by NGS, in the future it will be essential to ensure that the information is comparable, to allow it to be rapidly searched and analysed.

A number of open-access databases are already in place to facilitate the sharing of genomic data. These focus on either specific pathogens or specific sectors. For example, the
Global Initiative on Sharing All Influenza Data (GISAID) gathers the sequence data of influenza viruses from outbreaks around the world (11) and from other influenza sequence databases (12), while the Genome Trakr Network in the United States collects and shares genomic data from foodborne pathogens. However, with COMPARE, a single global platform enables the open sharing of genomic information across sectors, countries and pathogen types. Equally importantly, the project aims at harmonising the methods used by scientists, authorities, doctors and organisations around the world to collect samples, generate genome sequencing data and carry out risk assessments. Figure 1 illustrates the key elements of COMPARE.

A diverse range of stakeholders are involved in COMPARE. They include some who act as data providers, others who are primarily information users, and many who are likely to function as both (3). Users include professionals working in public health, food safety, animal health and wildlife, who are involved at various levels of research. Public authorities and private companies are also expected to use and benefit from the system. Key elements of the COMPARE project include (3, 13):

- Risk-assessment models and risk-based strategies, which guide and structure sample and data collection for NGSbased analyses to enhance the capacity to detect potential disease outbreaks. As part of the research conducted since COMPARE began, an inventory of existing sampling protocols has been developed to map the type of samples that are currently recommended for known diseases in the public and animal health sectors.

- Harmonised standards and analytical workflows for sample processing and sequencing, which generate high-quality NGS data in combination with relevant meta-data for pathogen detection and typing across sample types, pathogens and domains. Since the start of the project, an inventory of commonly used protocols with respect to the collection, handling, transport and storage of samples has been created. Pipelines for sampling processes before sequencing were also developed and initial laboratory operating procedures have been prepared.

- Analytical workflows for generating actionable information, which allow sequence- and meta-data to be interpreted and used when taking decisions in frontline diagnostics, foodborne-pathogen surveillance, outbreak detection, and epidemiological analysis. To date, a database of reference genomes, covering some of the most important foodborne pathogens of public health relevance, has been constructed, based on publicly available genomes.

- The data and information platform, which provides the technical backbone for the elements previously described, enabling the rapid sharing and analysis of pathogen genomics data. It is intended to be a portal to enable 


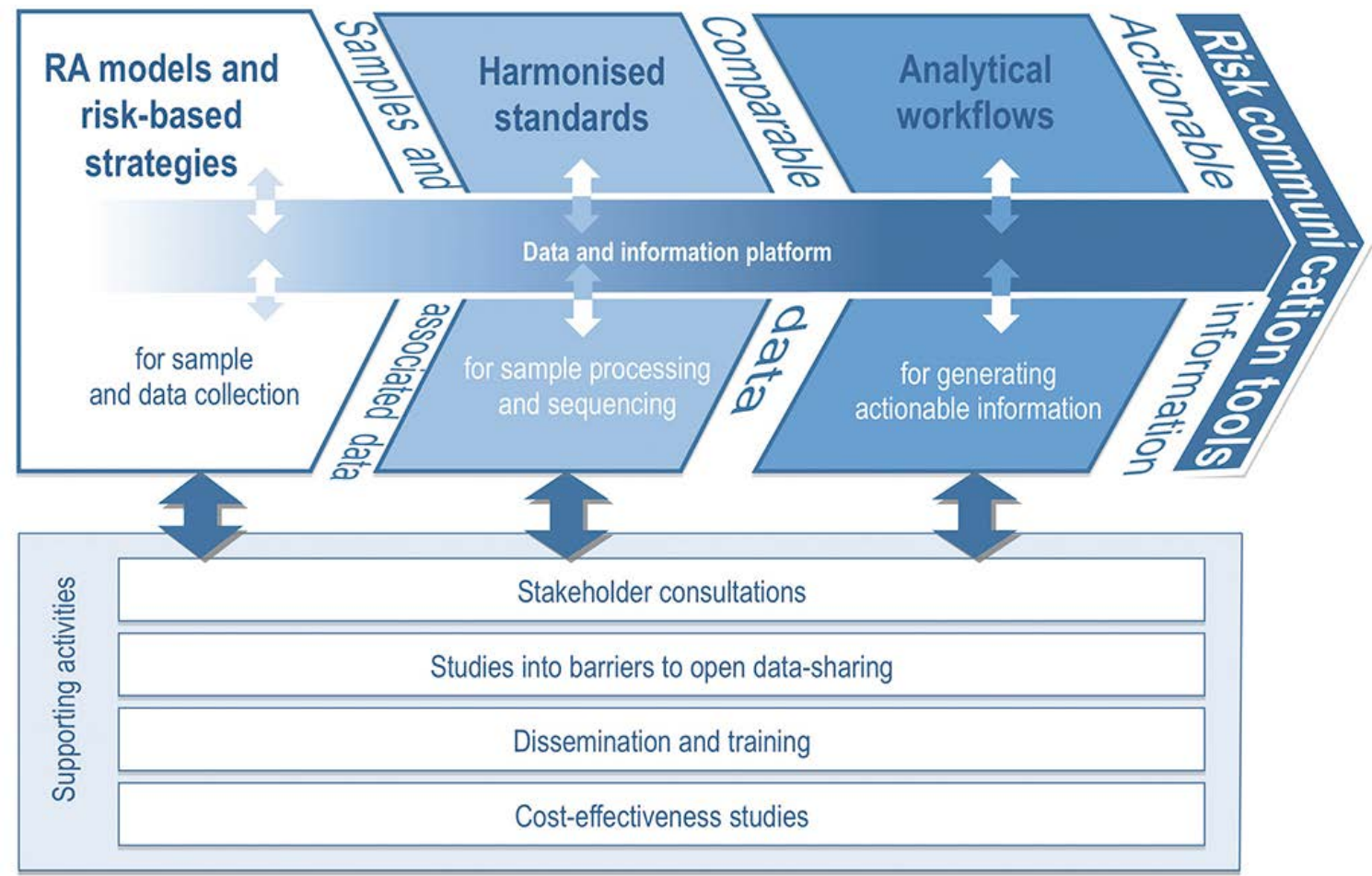

RA: Risk analysis

Fig. 1

Key elements of COMPARE (Collaborative Management Platform for detection and Analyses of [Re-] emerging and foodborne outbreaks)

users to report their data sets to the system and query, analyse and visualise COMPARE data, global public data of relevance and connected external data resources. A number of informatics tools have already been launched, including COMPARE Data Hubs and a Cloud environment providing a selection of bioinformatics tools.

- A risk communication toolbox, which supports the development of communication messages about findings, outbreaks and new opportunities discovered through COMPARE. The toolbox is aimed at stakeholders directly or indirectly involved in risk communication.

The final key element of COMPARE is research into its costeffectiveness, which aims, among other things, to identify the important elements in calculating the costs and benefits of COMPARE and similar systems, and to conduct related cost-effectiveness case studies.

\section{Towards a framework for assessing the cost-effectiveness of the COMPARE system}

As described above, and for the purpose of such case studies, COMPARE may be defined as a system for pathogen identification using NGS, with harmonised methods and a centralised data hub. To assess the cost-effectiveness of this type of system, a methodological framework must be defined before research can be conducted on its costs and benefits. The elements of such a framework include the:

- perspective of the analysis

- time frame of the analysis

- unit of effectiveness

- baseline

- cost and benefit types.

While these elements are essential for any cost-effectiveness or cost-benefit analysis, there is a high degree of variation in the specific approaches taken $(14,15)$. Therefore, as a basis for developing a suitable methodological framework, a literature review was conducted. It first targeted methodological guidance documents and meta-analyses of economic analyses conducted in the four key sectors covered by COMPARE (human health, food safety, animal health and wildlife). Secondly, it focused on previous costbenefit and cost-effectiveness analyses of current systems for pathogen identification and outbreak prevention, including those that use NGS, in these four sectors. The aim was to identify best practice as reflected in the guidance documents, and to review the methodological framework applied in practical cases. 
Relevant articles, reports and studies were identified through search engines and specialised databases and journals. A series of search term combinations were used, containing the keywords 'next-generation sequencing', 'costs', 'benefits', 'cost-effectiveness analysis', 'cost-benefit analysis', 'molecular typing', 'pathogen', 'food', 'pathogen identification', etc. In total, 105 documents were selected for further screening for their relevance. Based on this process, eight specific cost-effectiveness and cost-benefit studies were retained for in-depth review. The authors also identified guidance documents on cost-benefit and costeffectiveness analysis $(15,16,17,18,19,20,21,22,23,24$, $25)$, and included them in the review, where relevant. In the following section, they present the results of their review concerning the guidance provided, its implementation in practical cases, and the conclusions reached to construct a cost-effectiveness framework for the COMPARE system. More details on the studies identified are provided in Table I.

\section{Perspective of the analysis}

The chosen point of view from which an analysis is conducted determines its scope and which costs and benefits are included. While a narrow perspective considers only the direct costs of an intervention and the resulting benefits for its users, a wider point of view takes into account the social, health and economic costs and benefits accruing to society as a whole. Among narrow approaches, a common perspective adopted in health economics is that of the single benevolent decision-maker, whose aim is to maximise population health based on the available resources. The benefits taken into account are those that accrue to the target population; the costs are those provided for in the health budget (16).

At the other end of the spectrum, a societal approach considers the costs of an intervention that accrue to individuals beyond those directly involved, as well as the indirect impacts of the policy/programme. For example, from this perspective, the opportunity costs and the effect on income resulting from health improvements might be considered. Most cost-effectiveness guides argue that a societal perspective is the appropriate one to adopt in health economics, i.e. one which includes all costs, regardless of who pays them, and in which resources used by health interventions should be valued at the benefit foregone, since society cannot then use those resources for their next best use (health-related or otherwise) (16). However, a guidance document by the World Health Organization (WHO) on evaluating the costs and benefits of national surveillance and response systems observes that most studies are likely to adopt an approach that falls between the decision-maker's narrow perspective and the wider societal one, and that the decision on which viewpoint to take will depend upon the purpose of the analysis and its intended audience (22).
While a narrow perspective can make sense if decisions are taken at a micro level for a detailed patient population (e.g. decisions on which chemotherapy a cancer patient should receive), the limitations of a narrow perspective become more obvious if policies with more diverse consequences are being evaluated. In the United Kingdom, where a narrow perspective is usually adopted when evaluating curative healthcare interventions, there have been calls to broaden the perspective when public health interventions are assessed. In practice, about $50 \%$ of all genomic economic evaluations adopt a wider societal perspective (26). Among the studies reviewed, half applied a narrow perspective $(10,27,28,29)$. The other half adopted a wider societal perspective, with some combining the narrow and societal approaches, by considering the costs of a specific system, and comparing these with the benefits accruing to users/patients and the wider societal impacts $(30,31,32,33)$. In light of the broad scope of COMPARE and its expected far-reaching impacts, a wider societal perspective will be taken, possibly by combining specific analyses from a narrow perspective with a consideration of the wider societal benefits, where possible.

\section{Time frame}

Like the choice of perspective, the period covered by an analysis has an influence on the inclusion and calculation of various costs and benefits. Evaluating an intervention for a typical (or reference) year may bias the outcome against programmes that take a number of years to start providing benefits to their users. On the other hand, a long evaluation period is less feasible in practice, due to the relatively short time horizon in which health decisions are often taken (16). The methodological guidance documents reviewed provide several reasons for selecting longer time frames for economic evaluations of surveillance and response systems (22):

- new features of surveillance and response systems may take time to become effective; often there is a gap between the time when data is collected and when it is used for research/policy purposes

- for surveillance systems designed to detect outbreaks of new diseases (which are rare events), the reference period should be long enough to allow for the possibility of these events to occur

- the reference period should also be long enough for estimates of costs and benefits to be independent of epidemic-prone diseases with multi-year cycles, and other characteristics particular to the reference period.

A WHO guide to cost-effectiveness analysis, Making choices in health (16), suggests that generalised cost-effectiveness analysis should evaluate interventions over a reference 
Table I

Specific cost-effectiveness analyses and other relevant economic evaluations included in this review

\begin{tabular}{|c|c|c|c|c|c|c|}
\hline Reviewed literature & $\begin{array}{l}\text { Perspective } \\
\text { of the analysis }\end{array}$ & Time frame & Unit of effectiveness & Baseline & Cost types & Benefit types \\
\hline $\begin{array}{l}\text { Assessing the costs } \\
\text { and cost-effectiveness } \\
\text { of genomic sequencing } \\
\text { (10) }\end{array}$ & $\begin{array}{l}\text { Narrow perspective } \\
\text { (healthcare } \\
\text { expenditure) }\end{array}$ & 6 months & OALYS & $\begin{array}{l}\text { WGS patients } \\
\text { before disclosure of } \\
\text { WGS results/Non- } \\
\text { WGS patients }\end{array}$ & $\begin{array}{l}\text { Costs for gathering informed } \\
\text { consent, genomic sequencing, } \\
\text { confirming variants via Sanger } \\
\text { sequencing, medical care } \\
\text { costs following disclosure of } \\
\text { results, patient out-of-pocket } \\
\text { expenses }\end{array}$ & $\begin{array}{l}\text { A reduction in the number } \\
\text { of pathogenic and likely } \\
\text { pathogenic monogenic } \\
\text { findings for participants, } \\
\text { improved health-related } \\
\text { quality of life, early } \\
\text { identification and prevention } \\
\text { of potential threats }\end{array}$ \\
\hline $\begin{array}{l}\text { A qualitative approach } \\
\text { to measure the } \\
\text { effectiveness of active } \\
\text { avian influenza virus }\end{array}$ & $\begin{array}{l}\text { Narrow perspective } \\
\text { (direct surveillance } \\
\text { costs only) }\end{array}$ & $\begin{array}{l}\text { Reference year } \\
(2009)\end{array}$ & $\begin{array}{l}\text { Change in probability } \\
\text { of transmission of } \\
\text { HPAl from wild birds to } \\
\text { poultry, mutation from }\end{array}$ & $\begin{array}{l}\text { Situation without } \\
\text { active surveillance } \\
\text { of avian influenza } \\
\text { virus }\end{array}$ & $\begin{array}{l}\text { Organisation, materials, } \\
\text { sample-taking, laboratory } \\
\text { analysis and labour }\end{array}$ & $\begin{array}{l}\text { Increased awareness } \\
\text { and preparedness due to } \\
\text { surveillance, reduction in } \\
\text { probability of transmission }\end{array}$ \\
\hline
\end{tabular}

surveillance with

respect to its cost:

a case study from

Switzerland (11)

low-pathogenicity avian

influenza into HPAl in

poultry, and transmission

of HPAI to other poultry

holdings, given a primary

outbreak

Modelling the costeffectiveness of the

IDSR system: meningitis

in Burkina Faso (12)

Narrow perspective Pre-IDSR

(healthcare provider) period

(1996-2002)

and post-

IDSR period

(2003-2007)

Cost-effectiveness

analysis of diagnostic options for PCP (13)

An economic evaluation of PulseNet (14)
Narrow perspective in developing countries)

Societal perspective

(for benefits,

Data collected Reduction in reported perspective of between 1994 illnesses

health agencies

towards costs)

Proportion of PCP patients successfully treated and total
Number of cases, deaths or sequelae averted

Outbreaks before implementation of IDSR system diagnostic and treatment cost per life year gained

Comparison between different options

Pre-PulseNet situation in states
Personnel, transportation items, office consumable goods, public awareness campaigns, laboratory and response materials and supplies, meningitis case management and capital

Materials and personnel time

Correct diagnosis, successful treatment, life years gained

Cases, deaths or sequelae averted

\section{Programme costs}

Improved information, enhanced industry accountability, more rapid recalls, cost savings due to averted medical costs/ productivity losses, improvements in outbreak detection, reduction in foodborne illness

Comparison

between different coordination options in the absence of a formal EU-wide network system for public health laboratories

Costs and benefits
of a subtype-specific
surveillance system for
identifying Escherichia
coli 0157:H7 outbreaks (16)

An economic evaluation of the control of three notifiable fish diseases in the United Kingdom (17)

EU: European Union APAl: highly pathogenic avian influenza Societal perspective 5 years

(for benefits, (2013 or 2014)

networks and EU authorities towards costs)

Societal perspective

Net present value calculated over a 10 -year time horizon N/A

\section{Scenario in the absence of a subtype-specific surveillance system}

$\mathrm{N} / \mathrm{A}$

or limited disease

Staff costs, capital equipment costs, costs of consumable materials, travel and accommodation costs, shipping costs, subcontracting costs and costs of services

Labour and equipment costs (equipment, laboratory scientists, analysing isolates, investigating an outbreak present value of outbreak costs, annual operating costs)

Eventual outbreak cost, impacts across the industry plus social or welfare costs to wider society, costs of implementing surveillance
Economic savings from E. coli 0157:H7 cases averted (medical costs, productivity losses, lost lifetime earnings)

Monetary benefits (avoided private and social costs of potential disease outbreaks) monetary benefits networks and for society over all) 
period of ten years after full implementation. More specifically, the analysis should include the start-up costs before full implementation, total costs during the tenyear period, and all health effects that continue to occur beyond the reference period. While the feasibility of long reference periods also depends on data availability, this is a less relevant obstacle for hypothetical and modelling studies. When estimating the costs and effects over long time horizons, the choice of an appropriate discount rate for converting the values to their present worth is of key importance, as this may significantly affect results (26). While there is a large body of literature in this respect, there is no broad consensus across sectors and authors as to which discount rates are appropriate in what context. Recent general guidance provided by the European Commission for assessments in a regulatory context suggests a discount rate of $4 \%$ if costs and benefits are considered from the point of view of society as a whole, and recommends undertaking sensitivity analysis of the discount rate when it is applied over long time frames (24). The WHO suggests a discount rate of $3 \%$, and agrees on the need to conduct sensitivity analysis (16), while other guidance documents propose a discount rate of $3.5 \%$ (21).

A number of different time frames were applied in the studies reviewed, from studies focusing on a reference period of six months $(10)$ or a year $(27,31)$ to time frames of five to 15 years $(30,32)$. For other studies, the time frame was either unspecified or insignificant, depending on the research question. For example, for a cost-effectiveness analysis comparing various diagnostic options, the time frame was considered to be largely irrelevant as long as the comparison was made at the same point in time.

In the context of COMPARE, the most appropriate reference period will be chosen for each of the cost-effectiveness case studies. To the extent that specific outbreaks or outbreak scenarios will be scrutinised or modelled, the outbreak duration would be an appropriate reference period.

\section{Unit of effectiveness}

The unit of effectiveness is a measure of a quantifiable outcome that is central to the objectives of the programme/ intervention (23). The unit of effectiveness is used to calculate the denominator of the cost-effectiveness ratio, which in turn allows us to make comparisons between various interventions. In health economics, units of effectiveness relate to improvements in the length and/or in the quality of life. The most commonly used units in the area of human health include metrics such as disability-adjusted life years (DALYs) and quality-adjusted life years (QALYs) (16). Both QALYs and DALYs capture not only the impact of diseases on length of life but also multiple dimensions indicating the health-related quality of life. While QALYs are more popular when evaluating clinical interventions,
DALYs are more frequently used for evaluating public health interventions (34).

In the area of animal health, no similar measure is available, and economic analyses often quantify and compare outcomes on a monetary basis (e.g. by comparing outbreak and response costs with prevention costs). Among the studies reviewed, several different units of effectiveness were selected, including QALYs (10), the reduction in reported illnesses (30), or the number of cases prevented (28). The results of the literature review confirm that, while QALYs are a standard unit of effectiveness in health economics, in practice the units used to measure outcomes vary from study to study, reflecting the objectives of the intervention being scrutinised and the effects being captured (15). The methodological framework for the cost-effectiveness case studies will therefore consider the use of QALYs, but other outcome measures, such as the number of cases prevented or the reduction of outbreak costs, could also be used.

\section{Baseline}

Another key element of the methodological framework is the baseline - also known as the 'counterfactual scenario' or the 'comparator' - against which an intervention is measured. By comparing the proposed intervention to an alternative scenario, the difference that the intervention makes to a given outcome can be measured (22). To fully capture the effect of the policy or programme, the outcomes/effects must be measured for both the intervention as well as for the counterfactual (16). Cellini and Kee (23) define the baseline for the analysis as the status quo, or 'the state of the world in the absence of the program or policy'. According to this perspective, costs and benefits should only be considered in a cost-effectiveness or cost-benefit analysis if they would not have occurred in the absence of the intervention. In other words, when comparing the intervention to the status quo, only the marginal (or incremental) costs and benefits should be included in the assessment (23). This approach is often taken in cost-benefit analyses and corresponds to the EU guidance mentioned earlier (24).

The different baseline scenarios used in the studies reviewed reflect the diversity of research methods applied across these studies. Some studies compare situations with and without surveillance $(27,28,33)$, or consider different implementation options for a specific intervention (31). In one of the studies, researchers exploited the staggered adoption of the scrutinised programme (the PulseNet Network for Foodborne Disease Surveillance in the United States) across different states to estimate the impact of the programme. Using this natural experiment, they were able to compare states in which the intervention had been put in place with those states in which it had not yet been adopted (30). Two of the other studies reviewed also used the status quo, or absence of a given system or technology, 
as a baseline scenario, and this approach is also expected to be applied for the cost-effectiveness case studies $(24,32)$.

\section{Types of cost}

By definition, cost-benefit and cost-effectiveness analyses seek to collect, quantify and assess data about the costs of an intervention. Levin (25) defines costs as the value of the resources that are given up by society to implement the intervention, while Cellini and Kee (23) consider the overall costs of a programme as any negative impacts of that programme, added to the actual budgetary outlay. The WHO guidelines (16) differentiate between the costs of providing health interventions and the costs of accessing health interventions. Broadly, the categories of costs involved in 'providing' health interventions are the following:

- labour

- capital (such as building space and equipment)

- consumables (such as medical supplies and medication)

- overhead costs (such as electricity, water and maintenance).

The costs of 'accessing' healthcare interventions accrue to patients and their families and consist of the resources used and time involved in seeking or obtaining the intervention.

The guidance documents and studies reviewed by the authors provide a wide range of cost categorisations, including cost categories that correspond to the steps involved in an intervention (26) (for a detailed overview, refer to Table I).

Differences in the choice of costs (and benefits) included in an analysis depend to some extent on the perspective taken. From the point of view of the health or veterinary services provider or decision-maker, only the direct costs (and benefits) of the intervention are considered. For example, a focus on programme costs can imply a decision to leave out indirect costs, such as the costs borne by other government bodies, welfare losses from premature death, and reduced quality of life due to illness (30). In contrast, from a societal perspective, the wider social, health and economic costs (and benefits) have to be taken into account, regardless of who pays (or benefits) from those effects $(15,35)$.

Another factor that contributes to differences in cost categorisation across studies is the variety of terms used to describe largely similar cost types. In fact, in a majority of the studies reviewed, cost types can be grouped into the four main cost categories proposed by WHO: labour, capital, consumables and overhead costs (16). First, all the relevant studies systematically monetised staff time, focusing on various categories of personnel, including laboratory scientists, healthcare workers, clinicians and nurses. Secondly, most of the analyses accounted for capital costs representing investments at a single point in time, including those related to the construction of the building/laboratory and the purchase of equipment. Third, some of the studies calculated the cost of consumables, a category encompassing materials that are used up as a good or service is provided. These could, for example, consist of medical supplies or materials required for specimen collection and diagnostic test procedures. Overhead costs are also considered in several of the studies reviewed, and remaining cost types can be grouped under 'other costs' (depending on the subject area, perspective and level of detail used), leaving a total of five broadly applicable cost categories.

\section{Benefit types}

While ultimately the cost-effectiveness ratio(s) of the interventions/alternatives considered are based on one or several key measures of outcome, the benefits of the intervention are likely to be more far-reaching and numerous in practice. When evaluating the costs and benefits of national surveillance and response systems, WHO lists the following types of benefits that may arise as a result of such systems:

- benefits derived from averting cases

- benefits derived from averting deaths

- benefits of fewer social and economic disruptions (including disruptions to trade and tourism), when epidemics are averted

- social and psychological benefits stemming from less apprehension and greater peace of mind when large outbreaks of serious infectious diseases are rare or nonexistent (22).

Cellini and Kee (23) suggest identifying and classifying benefits (and costs) according to whether they are real benefits or merely transfers: direct or indirect, tangible or intangible, and financial or social. Based on these categories, the authors discuss the following examples of benefit types:

- non-market goods and services, such as social benefits, that cannot be readily estimated using market prices and budgets

- cost avoidance or cost savings

- time saved

- increased productivity.

Once again, the range of benefits considered depends on the perspective taken as well as the type of analysis undertaken (i.e. cost-effectiveness or cost-benefit). The reviewed 
cost-benefit analyses tended to quantify and monetise certain key benefits, describing additional benefits qualitatively.

An approach for estimating the wider benefits of surveillance and detection systems from a more macro perspective focuses on the value of information that surveillance and detection systems provide. One framework that could be used to quantify the value of more and better information facilitated through systems such as COMPARE is the socalled 'value of information' (VOI) framework. The VOI framework is developed within statistical decision theory and has been applied in healthcare and other fields (36, 37, 38). The key idea behind VOI is that the choice between several policy options is distinct from the choice of whether or not additional information should be collected by financing research, in order to inform the choice between these policy options. The value of information is determined by assessing to what extent more information can result in better decisions that yield a higher expected return (e.g. through averted cases, reduced outbreaks and related gains in productivity, quality of life, etc.), when compared to situations in which there is less information. Information is valuable because it reduces the expected costs of uncertainty surrounding various policy options.

In addition, surveillance and detection systems may provide a sense of safety to populations, or 'greater peace of mind', as noted before (22). Although this is a difficult element to value, it is a relevant benefit from the perspective of policymakers, as well as from a welfare economics perspective. The feeling of unsafety in countries facing an outbreak can be disruptive and unsettling. It is well known that the value of safety or avoiding losses can be high, but methods to determine these values are currently lacking. An analysis of the value of safety and its quantification, as well as the development of related methodological approaches, will be the focus of the next stage of the cost-effectiveness analysis of the COMPARE project.

\section{Conclusion}

COMPARE has the potential to bring about significant benefits in a variety of areas, including outbreak prevention and response, diagnostic improvements, and a resulting improvement in the well-being of the population (including in regard to their perceived safety). The costs, however, are also substantial. The cost-effectiveness case studies accompanying the COMPARE project aim to weigh these costs against the benefits, by quantifying them in monetary terms or through the use of one or more relevant units of effectiveness.

Possible case studies include the 2014 outbreak of the Ebola virus in western Africa, the outbreak of highly pathogenic avian influenza H5N8 virus in 2014, the 2011 outbreak of Shiga-toxin-producing E. coli in Germany, and more general themes, such as Salmonella surveillance. The cost-effectiveness studies accompanying the COMPARE project will provide insights into the extent to which public expenditure on this system, or other pathogen identification systems using NGS with harmonised methods and a centralised data hub, is justified by its benefits for users and society. Moreover, it will serve to guide further refinement of such a system, with a view to improving its overall costeffectiveness. 


\title{
Élaboration d'un cadre d'évaluation du rapport coûts-efficacité de COMPARE, plate-forme mondiale d'échange de données de séquençage sur les agents pathogènes
}

\author{
F. Alleweldt, Ş. Kara, A. Osinski, P. van Baal, K. Kellerborg, F.M. Aarestrup \\ \& M. Koopmans
}

\begin{abstract}
Résumé
L'analyse des données sur le génome des agents pathogènes grâce au séquençage de nouvelle génération (SNG) joue un rôle de plus en plus important dans les enquêtes sur les foyers de maladies et contribue à l'élaboration de stratégies de réponse. Si cette technologie a été utilisée avec succès pour élucider la cause des certains foyers et pour les contrôler, une application plus large du SNG dépend également de sa rentabilité. La plate-forme COMPARE (plate-forme de gestion collaborative pour la détection et l'analyse des foyers émergents et ré-émergents et des toxi-infections alimentaires) est un projet de grande envergure financé par l'Union européenne, visant à mettre en place une plate-forme mondiale d'échanges et d'analyse des données de séquençage de nouvelle génération et à améliorer ainsi l'identification précoce, le confinement et l'atténuation des maladies infectieuses émergentes et des foyers de toxiinfections alimentaires. Les auteurs présentent le projet ainsi que les résultats d'une étude bibliographique intégrant des analyses pertinentes coûts-avantages et coûts-efficacité réalisées dans le passé. Ils soulignent également les enseignements de ces analyses pour l'élaboration d'un cadre méthodologique d'évaluation de la relation coûts-efficacité applicable au système COMPARE et à $d$ 'autres systèmes similaires.
\end{abstract}

\section{Mots-clés}

Agent pathogène - COMPARE - Coûts-avantages - Coûts-efficacité - Détection Informations sur le génome - Séquençage de nouvelle génération - Surveillance.

\section{Concepción de un método para evaluar la relación costo-eficacia de COMPARE, dispositivo mundial de intercambio de datos de secuencias de patógenos}

\author{
F. Alleweldt, Ş. Kara, A. Osinski, P. van Baal, K. Kellerborg, F.M. Aarestrup \\ \& M. Koopmans
}

\section{Resumen}

El análisis de datos genómicos de los patógenos con ayuda de técnicas de secuenciación de próxima generación es un componente cada vez más importante de la investigación de brotes infecciosos, que resulta de utilidad para guiar las medidas de respuesta. Aunque estas técnicas ya se han utilizado con éxito para elucidar y combatir brotes de enfermedad, su aplicación generalizada también dependerá de la relación costo-eficacia que ofrezcan. COMPARE (acrónimo inglés de uplataforma de gestión colectiva para la detección y análisis de brotes (re)emergentes y de transmisión alimentaria») es un vasto proyecto financiado por la Unión Europea que apunta a instituir un dispositivo mundial de 
intercambio y análisis de datos de secuenciación de próxima generación y lograr así más eficacia en la rápida identificación, contención y mitigación de brotes de transmisión alimentaria y de enfermedades infecciosas emergentes. Los autores exponen el proyecto y presentan los resultados de un repaso bibliográfico de anteriores análisis de las relaciones costo-beneficio y costo-eficacia de estas técnicas. Además, explican brevemente lo que puede aportar un marco metodológico para evaluar la relación costo-eficacia del sistema COMPARE y de otros sistemas similares.

\section{Palabras clave}

COMPARE - Detección - Información genómica - Patógeno - Relación costo-beneficio Relación costo-eficacia - Secuenciación de próxima generación - Vigilancia.

\section{References}

1. Goldberg B., Sichtig H., Geyer C., Ledeboer N. \& Weinstock G.M. (2015). - Making the leap from research laboratory to clinic: challenges and opportunities for nextgeneration sequencing in infectious disease diagnostics. mBio, 6 (6), 1-10. doi:10.1128/mBio.01888-15.

2. Woolhouse M.E.J., Rambaut A. \& Kellam P. (2015). - Lessons from Ebola: improving infectious disease surveillance to inform outbreak management. Sci. Transl. Med., 7 (307), 1-8. doi:10.1126/scitranslmed.aab0191.

3. Collaborative Management Platform for detection and Analyses of (Re-) emerging and foodborne outbreaks in Europe (COMPARE) (2014). - Project proposal. COMPARE, Copenhagen. Available at: http://cordis.europa.eu/project/ rcn/194068_en.html (accessed on 10 April 2017).

4. Köser C., Holden M., Ellington M., Cartwright E., Brown N., Ogilvy-Stuart A., Hsu L., Chewapreecha C., Croucher N., Harris S., Sanders M., Enright M., Dougan G., Bentley S., Parkhill J., Fraser L., Betley J., Schulz-Trieglaff O., Smith G. $\&$ Peacock S. (2012). - Rapid whole-genome sequencing for investigation of a neonatal MRSA outbreak. N. Engl. J. Med., 366 (24), 2267-2275. doi:10.1056/NEJMoal109910.

5. Joensen K., Scheutz F., Lund O., Hasman H., Kaas R., Nielsen E. \& Aarestrup F. (2014). - Real-time whole-genome sequencing for routine typing, surveillance, and outbreak detection of verotoxigenic Escherichia coli. J. Clin. Microbiol., 52 (5), 1501-1510. doi:10.1128/JCM.03617-13.

6. Harris S., Cartwright E., Török M., Holden M., Brown N., Ogilvy-Stuart A., Ellington M., Quail M., Bentley S., Parkhill J. \& Peacock S. (2013). - Whole-genome sequencing for analysis of an outbreak of meticillin-resistant Staphylococcus aureus: a descriptive study. Lancet Infect. Dis., 13 (2), 130-136. doi:10.1016/S1473-3099(12)70268-2.
7. Hendriksen R., Price L., Schupp J., Gillece J., Kaas R., Engelthaler D., Bortolaia V., Pearson T., Waters A., Upadhyay B., Shrestha S., Adhikari S., Shakya G., Keim P. \& Aarestrup F. (2011). - Population genetics of Vibrio cholerae from Nepal in 2010: evidence on the origin of the Haitian outbreak. MBio, 2 (4), 1-6. doi:10.1128/mBio.00157-11.

8. Zankari E., Hasman H., Kaas R., Seyfarth A., Agersø Y., Lund O., Larsen M. \& Aarestrup F. (2013). - Genotyping using wholegenome sequencing is a realistic alternative to surveillance based on phenotypic antimicrobial susceptibility testing. J. Antimicrob. Chemother., 68 (4), 771-777. doi:10.1093/jac/ dks496.

9. Eyre D., Golubchik T., Gordon N., Bowden R., Piazza P., Batty E., Ip C., Wilson D., Didelot X., O'Connor L., Lay R., Buck D., Kearns A., Shaw A., Paul J., Wilcox M., Donnelly P., Peto T., Walker A. \& Crook D. (2012). - A pilot study of rapid benchtop sequencing of Staphylococcus aureus and Clostridium difficile for outbreak detection and surveillance. Br. Med. J. Open, 2 (3), 1-10. doi:10.1136/bmjopen-2012-001124.

10. Christensen K., Dukhovny D., Siebert U. \& Green R. (2015). - Assessing the costs and cost-effectiveness of genomic sequencing. J. Personal. Med., 5 (4), 470-486. doi:10.3390/ jpm5040470.

11. Global Initiative on Sharing All Influenza Data (GISAID) (2017). - Freunde von GISAID, Münich. Available at: http:// platform.gisaid.org/epi3/frontend\#3fc16c (accessed on 15 May 2016).

12. Joint World Organisation for Animal Health (OIE)/Food and Agriculture Organization (FAO) Worldwide Scientific Network for the Control of Avian Influenza (OFFLU) (2016). - OFFLU guidance on animal influenza sequence databases and links to influenza sequence databases. OIE, Paris \& FAO, Rome. Available at: www.offlu.net/index.php?id=113 (accessed on 7 September 2016). 
13. Collaborative Management Platform for Detection and Analyses of (Re-) Emerging and Foodborne Outbreaks in Europe (COMPARE) (2016). - Update year 1. COMPARE, Copenhagen. Available at: www.compare-europe.eu/Library/ Project-Documents (accessed on 15 June 2016).

14. Marsh T.L., Pendell D. \& Knippenberg R. (2017). - Animal health economics: an aid to decision-making on animal health interventions - case studies in the United States of America. In The economics of animal health (J. Rushton, ed.). Rev. Sci. Tech. Off. Int. Epiz., 36 (1), 137-145. doi:10.20506/rst.36.1.2617.

15. Babo Martins S. \& Rushton J. (2014). - Cost-effectiveness analysis - adding value to assessment of animal health, welfare and production. Rev. Sci. Tech. Off. Int. Epiz., 33 (3), 681-689. doi:10.20506/rst.33.3.2312.

16. Tan-Torres Edejer T., Baltussen R., Adam T., Hutubessy R., Acharya A., Evans D.B. \& Murray C.J.L. (2003). - Making choices in health: WHO guide to cost-effectiveness analysis. World Health Organization (WHO), Geneva. Available at: www.who.int/iris/handle/10665/42699 (accessed on 10 April 2017).

17. Gittinger J.P. (1982). - Economic analysis of agricultural projects, 2nd Ed. Johns Hopkins University Press, Baltimore, Maryland.

18. Drummond M.F., Sculpher J., Torrance G.W., O’Brien B.J. \& Stoddart G.L. (2005). - Methods for the evaluation of health care programs, 3rd Ed. Oxford University Press, New York.

19. Hutubessy R.C.W., Bendib L.M. \& Evans D.B. (2001). Critical issues in the economic evaluation of interventions against communicable diseases. Acta Trop., 78 (3), 191-206. doi:10.1016/S0001-706X(00)00176-5.

20. Petitti D.B. (2000). - Meta-analysis, decision-analysis, and cost-effectiveness analysis - methods for quantitative synthesis in medicine, 2nd Ed. Oxford University Press, New York.

21. Her Majesty's Treasury (2015). — The Green Book: appraisal and evaluation in central government (last updated on 20 October 2015). HM Treasury, London.

22. Anker M. \& World Health Organization (WHO) (2005). Evaluating the costs and benefits of national surveillance and response systems: methodologies and options. WHO, Lyon, France, 48 pp. Available at: www.who.int/iris/ handle/10665/69335 (accessed on 10 April 2017).

23. Cellini S. \& Kee J. (2010). - Cost-effectiveness and costbenefit analysis. In Handbook of practical program evaluation (J. Wholey, H. Hatry \& K. Newcomer, eds). Jossey-Bass, San Francisco, 493-530.

24. European Commission (EC) (2015). - Better regulation toolbox. EC, Brussels. Available at: http://ec.europa.eu/smartregulation/guidelines/toc_tool_en.htm (accessed on 15 June 2016).
25. Levin H.M. (1995). - Cost-effectiveness analysis, In International encyclopedia of economics of education, 2nd Ed. (M. Carnoy, ed.). Pergamon Press, Oxford, 381-386. Available at: www.c3l.uni-oldenburg.de/cde/econ/readings/ levin95.pdf (accessed on 1 June 2016).

26. Buchanan J., Wordsworth S. \& Schuh A. (2013). - Issues surrounding the health economic evaluation of genomic technologies. Pharmacogenomics, 14 (15), 1833-1847. doi:10.2217/pgs.13.183.

27. Häsler B., Howe K.S., Hauser R. \& Stärk K.D.C. (2012). A qualitative approach to measure the effectiveness of active avian influenza virus surveillance with respect to its cost: a case study from Switzerland. Prev. Vet. Med., 105 (3), 209-222. doi:10.1016/j.prevetmed.2011.12.010.

28. Somda Z.C., Perry H.N., Messonnier N.R., Djingarey M.H., KiS.Q. \& Meltzer M.I. (2010). - Modeling the cost-effectiveness of the integrated disease surveillance and response (IDSR) system: meningitis in Burkina Faso. PLoS ONE, 5 (9), e13044. doi:10.1371/journal.pone.0013044.

29. Harris J.R., Marston B.J., Sangrujee N., DuPlessis D. \& Park B. (2011). - Cost-effectiveness analysis of diagnostic options for pneumocystis pneumonia (PCP). PLoS ONE, 6 (8), e23158. doi:10.1371/journal.pone.0023158.

30. Scharff R.L., Besser J., Sharp D.J., Jones T.F., Peter G.S. \& Hedberg C.W. (2015). - An economic evaluation of PulseNet: a network for foodborne disease surveillance. Am. J. Prev. Med., 50 (5, Suppl. 1), S66-S73. doi:10.1016/j. amepre.2015.09.018.

31. Civic Consulting (2016). - Study on cost-benefit analysis of reference laboratories for human pathogens: draft final report. European Commission, Brussels, 272 pp. doi:10.2818/788468.

32. Elbasha E., Fitzsimmons T. \& Meltzer M. (2000). - Costs and benefits of a subtype-specific surveillance system for identifying Escherichia coli O157:H7 outbreaks. Emerg. Infect. Dis., 6 (3), 293-297. doi:10.3201/eid0603.000310.

33. Moran D. \& Fofana A. (2007). - An economic evaluation of the control of three notifiable fish diseases in the United Kingdom. Prev. Vet. Med., 80 (2-3), 193-208. doi:10.1016/j. prevetmed.2007.02.009.

34. Gold M., Stevenson D. \& Fryback D. (2002). - HALYS and QALYS and DALYS, Oh My: Similarities and differences in summary measures of population health. Annu. Rev. Public Hlth, 23, 115-134. doi:10.1146/annurev. publhealth.23.100901.140513.

35. Rushton J. \& Upton M. (2006). - Investment in preventing and preparing for biological emergencies and disasters: social and economic costs of disasters versus costs of surveillance and response preparedness. In Biological disasters of animal origin. The role and preparedness of veterinary and public health services (M. Hugh-Jones, ed.). Rev. Sci. Tech. Off. Int. Epiz., 25 (1), 375-388. doi:10.20506/rst.25.1.1671. 
36. Pratt J., Raiffa H. \& Schlaifer R. (1995). - Statistical decision theory. MIT Press, Cambridge, Massachusetts.

37. Claxton K. (1999). - The irrelevance of inference: a decisionmaking approach to the stochastic evaluation of health care technologies. J. Hlth Econ., 18 (3), 341-364. doi:10.1016/ s0167-6296(98)00039-3.
38. Yokota F. \& Thompson K. (2004). - Value of information analysis in environmental health risk management decisions: past, present, and future. Risk Anal., 24 (3), 635-650. doi:10.1111/j.0272-4332.2004.00464.x. 